\title{
Segment Information: What Do European Small and Mid-Caps Disclose?
}

\author{
Fréderic Demerens ${ }^{1}$, Pascale Delvaille ${ }^{1}$, Anne Le Manh ${ }^{1}$, Jean-Louis Paré ${ }^{2}$ \\ ${ }^{1}$ ESCP Europe, Paris, France \\ ${ }^{2}$ Novancia Business School, Paris, France \\ Correspondence: Anne Le Manh, ESCP Europe, Financial Reporting and Audit Departement, Paris campus, 79 \\ avenue de la République, 75011 Paris, France.
}

Received: August 4, 2017

doi:10.5539/ibr.v10n11p42
Accepted: September 18, 2017

Online Published: September 29, 2017

URL: https://doi.org/10.5539/ibr.v10n11p42

\begin{abstract}
The adoption of the IFRS 8 accounting standard symbolises the IASB's dual commitment: an effort toward convergence and harmonisation with the American standard, but also an effort to optimise the standardisation process through an unprecedented study: a post-implementation review. Many studies have laid the groundwork for an implementation review of the standard, mostly focusing on large firms. However, intermediate-size companies - which are much more numerous - are also faced with the application of IFRS standards. In this context, our study aims to analyse the implementation of IFRS 8 by a sample of intermediate-size European listed companies. Our research questions mainly focus on issues of compliance with the standard and the comparability of segment information reported by intermediate-size European companies. Our findings reveal a lower level of compliance than that observed in previous studies on samples of multinationals. The intermediate-size European companies in our sample use fewer segments and provide less information per segment, without however neglecting voluntary disclosures. Some significant differences emerge between companies depending on their country of domicile and their economic sector.
\end{abstract}

Keywords: segment information, IFRS 8, intermediate-size company, compliance

\section{Introduction}

When the IASB published the IFRS 8 Operating Segments standard in November 2006, many criticisms were levelled against the standard setter's decision, especially in Europe. Largely based on the American SFAS 131, this new standard broke with the approach that had been followed in the previous standard (IAS 14) and caused some people to fear a decline in the quality of segment information reported. Yet given the diversification and internationalisation of companies, segment information is essential for users of financial information (Day 1986 ; Previts, Bricker, Robinson, \& Young,1994) . Favouring the managerial approach based on internal reporting in order to reduce costs, to shorten reporting times, and to optimise information quality and relevance to users, the IFRS 8 standard tends to disregard geographic information somewhat and moves away from the former IAS 14 standard on certain points. In a historically unusual step in the EU process of adopting IFRS standards, the European Parliament asked the European Commission to carry out a study of the potential impact of the standard before ruling on its adoption - in spite of the endorsement by EFRAG and ARC. The standard was finally adopted by the Commission a few months later on the condition that it presents a follow-up report to Parliament. This was also the first standard to be subjected to a post-implementation review conducted by the IASB. This step was introduced into the IASB's formal consultation process (due process) in 2008 and in principle is limited to major or disputed standards and amendments.

The purpose of our study is to contribute to the current debate on the effects of the implementation of IFRS 8 . Our review of the literature shows that the few studies that have so far been conducted on this topic tend to focus on large, listed companies and do not pay much attention to any differences in practices that may exist between companies depending on their country of domicile. We have therefore decided to focus on IFRS 8 implementation by European "intermediate-size" listed companies (defined below). Our study examines a sample of 197 intermediate-size listed companies in Germany, France, the UK and Italy for which we have manually collected data on segment information published in their 2010 annual report. The main objective of our study is to better understand how European intermediate-sized companies apply the IFRS 8 standard. 
The first part of this paper briefly outlines the requirements of the IFRS 8 standard for disclosing segment information. Our review of the literature and research questions are developed in the second part. The third part describes our research methodology. Our findings are presented and discussed in the fourth part.

\section{Segment Information under IFRS}

The IFRS 8 standard, which came into effect on 1 January 2009, requires companies to adopt a managerial approach in disclosing segment data. This managerial approach means that they have to provide information the way it is used by the chief operating decision maker (CODM). This information does not necessarily conform to the requirements of other IFRS standards, which was not the case of IAS 14 which required segment information to be prepared in accordance with the accounting principles and methods used in preparing financial statements. The managerial approach is generally deemed to be more suitable because it is based on the information as it is "seen" and "used" by managers. Most financial analysts appreciate having information that is identical to that used by chief executives, but they fear that companies will change their segmentation more often, making financial statements less comparable ( CFA-Institute 2007; Papa \& Ciesielski 2009 ). Apart from choosing the managerial approach, which was the most important issue in the debate on moving to a new standard, other elements were also modified in the new standard. For example, the amount of compulsory information to be reported was substantially reduced, with several items only being reported if they are actually provided to the CODM. The segment information required by IFRS 8 is presented in Table 1.

Table 1. Items required under IFRS 8

Mandatory general information :

- Explanation on segmentation : factors used to identify the entity's reportable segments

- Types of products and services from which each reportable segment derives its revenues

Mandatory items (for each segment)

- Measure of profit or loss

- $\quad$ Segment assets, if regularly provided to chief operating decision maker

- $\quad$ Segment liabilities, if regularly provided to chief operating decision maker

Items to be disclosed if they are included in the measure of segment profit/loss reviewed by chief operating decision maker, or otherwise regularly provided to the chief operating decision maker, even if not included in that measure of segment profit/loss.

- Revenue from external customers

- Revenues from transactions with other operating segments of the same entity

- Interest revenue

- Interest expense

- Depreciation and amortisation

- $\quad$ Equity method income

- Income tax expense/benefit

- Material non-cash items other than depreciation and amortisation

- Other material items

Balance sheet information to be disclosed if it is included in the measure of segment assets reviewed by chief operating decision maker, or otherwise regularly provided to the chief operating decision maker, even if not included in that measure of segment assets.

- $\quad$ Equity method investments

- Additions to non-current assets

Reconciliation of consolidated data with :

- Segment revenues

- Segment measures of profit or loss

- Segment assets (if they are disclosed)

- Segment liabilities (if they are disclosed)

- Other material items disclosed

Entity-wide disclosures: information to be disclosed if it is available and not already provided as a part of segment information

- Information about products and services :

- Revenues from external customers for each product or service

- Information about geographical areas

- Revenues from external customers (i) attributed to the entity's country of domicile and (ii) attributed to all foreign countries in total from which the entity derives revenues

- Non-current assets (i) located in the entity's country of domicile and (ii) located in all foreign countries in total in which the entity holds assets

- Information about major customers :

- If revenues from transactions with a single external customer amount to $10 \%$ or more of an entity's revenues, the entity shall disclose that fact 
The number of items that must necessarily be reported is very limited and, surprisingly, revenue from ordinary activities (turnover) is not among them. It is hard to imagine turnover not being included in the calculation of a segment's results, nor provided to the CODM. Even though not compulsory, this figure should be reported systematically.

\section{Literature Review and Research Questions}

The aim of our research is to make a survey of the segment information reporting practices of Intermediate-size European listed companies and analyse whether the information published complies with the requirements of IFRS 8. Numerous studies have been conducted on segment information and they may be grouped in three categories. The first contains studies that seek to identify the determinants of voluntary disclosure of segment data. The second covers research into the usefulness of segment information. The third category, which our literature review focuses on, contains studies that analyse in detail the segment information reported by companies. One set of studies examines the comparability of segment information reported, while another looks into the evolution of this information following the introduction of a new standard. Finally, we present the few studies that exist on the compliance of information reported with the requirements of the accounting standard in force at the time.

\subsection{Comparability of Segment Information Reported by Companies}

The first studies on segment information focused on comparing the practices of firms located in the same country and concluded that the segment information reported was weakly homogeneous ( Pacter 1970 ; Emmanuel \& Gray, 1977 ; Tyson \& Jacobs, 1987).

Other studies compare segment information reported by firms located in different countries and highlight national specificities, but all of them were carried out before the application of IFRS, when the accounting standards were different, depending on the country (Gray \& Radebaugh, 1984, Herrmann \& Thomas, 1996). To our knowledge, there has never been a study on the comparability of segment information reported by firms from different countries where all of them use the IFRS standard. A KPMG study (2010), based on a sample of 81 companies chosen at random from the largest 500 companies worldwide, reveals segment disparities in the implementation of IFRS 8 . It shows that $66 \%$ of the firms in the sample perform a segmentation by product or service, but that there are disparities depending on the type of activity. For example, the majority of agri-food companies $(80 \%)$ prefer geographic segmentation, while all the transport companies chose segmentation by product.

\subsection{Introduction of a New Standard and Segment Information Reported}

The first studies were carried out in an American business context, when the FASB adopted the SFAS 131 standard in 1997 to replace SFAS 14. Herrmann and Thomas (2000) observed that changing the definition of what constitutes a segment (shifting to an "operational" definition based on internal reporting) caused $68 \%$ of the companies in the sample to alter their segmentation. The impact of the shift to a managerial approach was therefore quite real. The number of segments reported tends to increase, as does the number of items while the amount of geographic information declines. Street, Nichols and Gray (2000) also observe an improvement in segment reporting (greater number of segments and more information published) for the largest American firms after adoption of the SFAS 131 standard. Thinner geographic information is also observed (steep decline in the disclosure rate of earnings by geographic area. On the contrary, Doupnik and Seese (2001) observe an improvement in the granularity (mainly the segmentation by country) of geographic information reported under the new SFAS 131 standard.

The first studies on the effects of the shift from IAS 14 to IFRS 8 appeared in 2012. Nichols, Street and Cereola (2012) studied the impact of the adoption of IFRS 8 on the segment information reported by 335 large European multinationals. ${ }^{1}$ For the majority of firms, they observe that while the number of segments had not changed with the shift to IFRS 8, the number of segment items reported dropped significantly. However, they observe an improvement in the granularity of the geographic data reported, contrary to what critics of IFRS 8 feared. Crawford, Extance and Helliar (2012) analyse the segment information reported by 151 British firms before and after adopting IFRS 8. Their findings are similar to those of Nichols et al. (2012): the number of segments reported rose slightly, but the number of items reported per segment dropped. Two studies carried out in

\footnotetext{
${ }^{1}$ Their sample was made up of companies in the top third of the market index of 14 European countries: Austria, Belgium, Denmark, Finland, France, Germany, Ireland, Italy, Luxembourg, Netherlands, Norway, Spain, Sweden and Switzerland.
} 
Australia obtained findings that differed somewhat from these. Kang and Gray ( 2012 ) and Bugeja, Czernkowski and Bowen (2012) observe an increase in both the number of segments and the number of items reported. In a study on the impact of the new standard on Italian firms, Pisano and Landriana (2012) pointed out that the companies operating in sectors with less competition reduced the amount of segment data reported.

\subsection{Conformity of the Information Reported with the IFRS Standard}

There are still very few studies that look at compliance with IFRS reporting requirements and most of them were carried out before 2001, i.e. before the IASB was founded, when IAS/IFRS were voluntarily adopted (Chatham, 2008 ; Street \& Gray,2002 ; Street \& Bryant, 2000 ).

Few studies look at the compliance of financial information reported by companies that are obliged to apply the IFRS standard. Based on a sample of 101 firms, Mechelli (2009) examines the extent to which Italian companies comply with the requirements of IAS 7 Cash flow statements during the first year IFRS standards were applied. He concludes that compliance is low for Italian firms. Nichols et al. (2012) do not analyse the extent to which European multinationals comply with the IFRS standard, but their study provides data on the frequency of reporting for the different items required by IFRS 8 .

\subsection{Research Questions}

Our study of the segment information reporting behaviour of Intermediate-size European listed companies is based on the following research questions:

1. What are the practices of intermediate-size companies in the area of segmentation?

1a. What is the preferred segmentation approach (by line of business, by geographic area, or a mixed approach)?

1b. How many segments are reported?

2. To what extent do intermediate-size companies comply with the requirements of the IFRS 8 standard?

3. What segment information is voluntarily reported by intermediate-size companies?

4. How many companies are early adopters of IFRS 8 ?

5. Are there any differences between German, French, Italian, and British companies in terms of segment information reporting?

6. Are there any differences in segment information reporting behaviour related to type of business activity?

\section{Methodology}

In setting up our sample we have used the official French definition of an intermediate-size company as specified by the 2008 French finance law ${ }^{2}$ : a company with between 250 and 4999 employees, turnover not exceeding $€ 1.5$ billion and a balance sheet total not exceeding $€ 2$ billion.

As data had to be collected manually, with two annual reports (2009 and 2010) per company, we decided to limit the number of firms to 300 at first in order to obtain our first results within a reasonable amount of time. We therefore decided to select companies from four European countries: the UK, France, Germany and Italy, first because their stock exchanges are among the largest in Europe and, second, to reflect the geographic diversity of the research team. Our initial selection of British, French, German and Italian intermediate-size companies was based on 2010 data from the Thomson ONE Banker database. Table 2 summarises the procedure for setting up the sample.

Table 2. Sample design

\begin{tabular}{|c|c|c|}
\hline French, German, British and Italian small and mid- caps for which net sales are $<1.5$ billion euros & & 1,510 \\
\hline Entities for which some items are missing & -98 & 1,412 \\
\hline Financial entities & -210 & 1,202 \\
\hline Companies for which the number of employees is less than 250 or more than 4,999 & -297 & 905 \\
\hline Companies for which the total assets is more than 2 billion euros & -16 & 889 \\
\hline Manually eliminated companies (as described in the paper) & -602 & 287 \\
\hline Companies with one or two missing annual reports & -46 & 241 \\
\hline Italian companies not analysed & -26 & 215 \\
\hline Single segment companies & -18 & 197 \\
\hline
\end{tabular}

Our initial sample was made up of 889 companies. In order to meet our starting objective of 300 companies, we manually reduced the sample using the following criteria:

${ }^{2}$ French law n ${ }^{\circ}$ 2008-776 on the modernisation of the economy, promulgated on 4 August 2008. 
- ruling out companies for which we could not get access to at least five studies by financial analysts ${ }^{3}$ working at brokerage firms for the 2007-2011 period in the Thomson One Banker database;

- randomly choosing one company out of three, making sure that the proportion of countries and other criteria (number of employees, turnover and balance sheet total) was virtually identical to the original selection.

We thus obtained a sample made up of 287 intermediate-size European listed companies. Finally, we eliminated companies for which we did not have two annual reports, 26 Italian companies that did not publish their annual report in English, and 18 mono-segment companies. The latter do not publish specific segment information either because they only have one line of business or because they only operate in one geographic area. Taking them into account would have biased our analysis of compliance with IFRS 8. The final sample was made up of 197 companies. Data enabling us to answer our research questions was then collected manually from the 2010 annual reports ${ }^{4}$ of these 197 companies. T-tests were done to show statistically significant variances in means.

\section{Findings}

\subsection{Description of the Sample}

At this stage in our research Italian companies are the least represented because in our sample (table 3), as explained above, those that do not publish an English version of their annual report were excluded from our sample. Companies were classified in five groups according to their GICS code (Global Industry Classification Standard). As shown in Table 4, the telecommunications and information technologies sector is the most represented with 68 companies ( $34 \%$ of the sample), followed by industrials ( $27 \%$ of the sample). The average turnover of companies in the sample is $€ 273$ million, their average balance sheet total is $€ 312$ million and the average number of employees is 1456 .

\subsection{Segmentation}

\subsubsection{Type of Segmentation}

We identified three types of approach used by the companies in our sample for presenting segments: by line of business (LOB), by geographic area and matrix. ${ }^{5}$ Table 3 shows that a large majority of companies (70\%) choose a segmentation by LOB. This finding is in keeping with previous studies. An LOB segmentation was chosen by $75 \%$ of companies in the Nichols et al. ( 2012 ) sample and 66\% of those in the KPMG study ( 2010 ). In our sample of intermediate-size companies, the French companies differed slightly from the others in that they used an LOB segmentation less frequently $(64 \%)^{7}$ while in the Nichols et al. ( 2012 ) sample German companies differed most from the others ( $87 \%$ of the 30 German companies chose this type of segmentation).

Table 3. Type of segmentation by country

\begin{tabular}{|c|c|c|c|c|c|c|c|c|}
\hline & \multicolumn{2}{|c|}{ LOB Segmentation } & \multicolumn{2}{|c|}{ GEO. Segmentation } & \multicolumn{2}{|c|}{ Matrix Segmentation } & \multicolumn{2}{|c|}{ Total } \\
\hline & $\mathbf{N}$ & $\%$ & $\mathbf{N}$ & $\%$ & $\mathbf{N}$ & $\%$ & $N$ & $\%$ \\
\hline Germany & 41 & $73 \%$ & 15 & $27 \%$ & - & - & 56 & $100 \%$ \\
\hline France & 32 & $64 \%$ & 15 & $30 \%$ & 3 & $6 \%$ & 50 & $100 \%$ \\
\hline UK & 49 & $70 \%$ & 18 & $26 \%$ & 3 & $4 \%$ & 70 & $100 \%$ \\
\hline Italy & 15 & $71 \%$ & 5 & $24 \%$ & 1 & $5 \%$ & 21 & $100 \%$ \\
\hline Total & 137 & $70 \%$ & 53 & $27 \%$ & 7 & $4 \%$ & 197 & $100 \%$ \\
\hline
\end{tabular}

\footnotetext{
${ }^{3}$ Reports by financial analysts will be used in future research

${ }^{4}$ All annual reports with a closing date in 2010 are considered as 2010 annual reports.

${ }^{5}$ Readers interested in an exhaustive presentation of the different segmentations will find many explanations and illustrations based on real cases from European blue chips in the article by Nichols et al. (2012).

${ }^{6}$ On a basis comparable to our classification, i.e. after removing companies that only report one segment in Nichols et al. (2012), we obtain $73 \%$ after grouping together the companies listed in the two "matrix" columns and $77 \%$ after grouping together the companies listed in the two "mixed" columns.

${ }^{7}$ Mainly because three intermediate-size French companies adopt a matrix segmentation (whereas no German or French company does so in the sample of Nichols et al. (2012).
} 
Table 4. Type of segmentation by sector

\begin{tabular}{|c|c|c|c|c|c|c|c|c|}
\hline & \multicolumn{2}{|c|}{ LOB Segmentation } & \multicolumn{2}{|c|}{ GEO. Segmentation } & \multicolumn{2}{|c|}{ Matrix Segmentation } & \multicolumn{2}{|l|}{ Total } \\
\hline & $\mathbf{N}$ & $\%$ & $\mathbf{N}$ & $\%$ & $\mathbf{N}$ & $\%$ & $N$ & $\%$ \\
\hline Consumer G\&S & 30 & $77 \%$ & 7 & $18 \%$ & 2 & $5 \%$ & 39 & $100 \%$ \\
\hline Energies et Matières Premières & 18 & $78 \%$ & 5 & $22 \%$ & - & - & 23 & $100 \%$ \\
\hline Health Care Care & 7 & $50 \%$ & 7 & $50 \%$ & - & - & 14 & $100 \%$ \\
\hline Industrials & 34 & $64 \%$ & 16 & $30 \%$ & 3 & $6 \%$ & 53 & $100 \%$ \\
\hline Information Tech. \& Telecom & 48 & $71 \%$ & 18 & $26 \%$ & 2 & $3 \%$ & 68 & $100 \%$ \\
\hline Total & 137 & $70 \%$ & 53 & $27 \%$ & 7 & $4 \%$ & 197 & $100 \%$ \\
\hline
\end{tabular}

Table 4 shows that there are disparities in the segmentation chosen depending on the sector, a finding which has already been highlighted in recent studies (KPMG 2010). For example, in our sample, a segmentation by LOB is much less frequent in the health care and industrials sectors, with geographic segmentation accounting for 50\% and $30 \%$ respectively of the companies in these two sectors, while the average for the sample as a whole is $27 \%$. It should be pointed out however that it is very hard to compare the choice of segmentation at the economic sector level (industry, services, etc.) for the various studies published recently given that codifications and groupings carried out by researchers are not identical.

The third type of segmentation is a combination of geographic segments and product/services/business lines called a "matrix" segmentation. It is only adopted by a small minority (4\%) of companies. No German company and no company in the energy and materials or health care sectors chose it.

In sum, based on our sample, intermediate-size companies appear to have adopted the same behaviour as the largest European companies by mostly choosing LOB segmentation.

\subsubsection{Number of Segments and Number of Items per Segment}

The number of segments reported as well as the number of items provided for each segment is frequently used to determine the quality of segment reporting and its comparability. The adoption of a new standard on segment reporting is a good reason to look at these two indicators.

Still, the various studies in this area lack uniformity of methodology. First of all, it is important to distinguish the operating segments defined by the standard from the different categories reported by firms. Companies often publish one or two columns that correspond to reconciling items or to "corporate" data or even to discontinued activities. In our study we only use "pure" operating segments and have therefore discarded any reconciling "columns". Second, the studies either present averages for their entire sample (total number of segments divided by the number of firms in the sample), or averages by segment type only for companies using that type of segmentation. We feel the second approach is sounder and provides a more accurate image of company practices.

Table 5 presents the number of segments reported depending on the type of segmentation chosen (a firm may report information in both LOB and geographic segmentations, whether in matrix or otherwise). We observe that the number of segments used by firms presenting an LOB segmentation is smaller than the number of segments used by firms presenting a geographic segmentation (3.2 vs. 3.82). For the sample as a whole, however, firms report less geographic information than information based on LOB segmentation.

Unsurprisingly, we observe that companies tend to favour their primary segmentation. Thus firms opting for a LOB segmentation report 3.15 operating segments on average with more than 11 items of information per segment, but they report 4.09 geographic segments with fewer than 2 items per segment. Companies opting for a geographic operating segmentation report 3.45 segments on average with 9.79 items per geographic segment compared with 3.60 segments and 1 item of information for their LOB segmentation. In both cases, the information provided in the "secondary segmentation" is often limited to turnover or perhaps an earnings indicator and the segments are few in number.

The recent study by Crawford et al. ( 2012 ) shows a smaller number of segments for small companies (FTSE 250 vs FTSE 100), regardless of whether the segmentation is LOB or geographic. Our findings were lower than those obtained by Crawford et al. (2012) for their sample as a whole, unless we compare the number of LOB operating segments for FTSE 250 companies (2.75). For Nichols et al. (2012) the average number of operating segments (regardless of segmentation type) is 4.19. The intermediate-size companies in our sample thus report a smaller number of segments, whether LOB or geographic, than has been observed in studies on larger companies. 
Table 5. Number of segments and number of items by segmentation type chosen to define operating segments

\begin{tabular}{|c|c|c|c|c|c|}
\hline & & \multicolumn{2}{|c|}{ LOB Segmentation } & \multicolumn{2}{|c|}{ GEO. Segmentation } \\
\hline \multicolumn{2}{|c|}{$\begin{array}{c}\text { Type } \\
\text { Of } \\
\text { Operating Segmentation } \\
\end{array}$} & Number of Segments & $\begin{array}{c}\text { Number of Items per } \\
\text { Segment }\end{array}$ & Number of Segments & $\begin{array}{l}\text { Number of Items per } \\
\text { Segment }\end{array}$ \\
\hline \multirow{3}{*}{ Total } & $N$ & 163 & 163 & 154 & 154 \\
\hline & Mean & 3.20 & 8.83 & 3.82 & 4.30 \\
\hline & Max. & 8.00 & 73 & 11.00 & 44 \\
\hline \multirow{3}{*}{$\begin{array}{c}\text { LOB } \\
(\mathrm{N}=137)\end{array}$} & $N$ & 137 & 137 & 94 & 94 \\
\hline & Mean & 3.15 & 11.64 & 4.09 & 1.93 \\
\hline & Max. & 8.00 & 73 & 11.00 & 19 \\
\hline \multirow{3}{*}{$\begin{array}{c}\text { GEO } \\
(\mathrm{N}=53)\end{array}$} & $N$ & 20 & 20 & 53 & 53 \\
\hline & Mean & 3.60 & 1.13 & 3.45 & 9.79 \\
\hline & Max. & 7.00 & 15 & 7.00 & 44 \\
\hline \multirow{3}{*}{$\begin{array}{l}\text { Matrix } \\
(\mathrm{N}=7)\end{array}$} & $N$ & 6 & 6 & 7 & 7 \\
\hline & Mean & 3.00 & 12.00 & 3.00 & 9.29 \\
\hline & Max. & 6.00 & 51 & 4.00 & 18 \\
\hline
\end{tabular}

The analysis of the number of segments and the number of items per segment by country (Table 6) allows us to identify potential differences in practices by country. German firms are slightly above the overall sample average except for the number of geographic items reported (statistically significant negative difference). The intermediate-size French companies use fewer segments on average, but report slightly more items per segment. They distinguish information concerning the country of domicile (France) less frequently and this is statistically significant. Overall and on average, British firms provide fewer LOB segment items. Finally, Italian firms tend to use a greater number of geographic segments.

Table 6. Number of segments and items by country

\begin{tabular}{|c|c|c|c|c|c|}
\hline & & \multicolumn{2}{|c|}{ LOB Segmentation } & \multicolumn{2}{|c|}{ GEO. Segmentation } \\
\hline \multicolumn{2}{|c|}{ Country } & $\begin{array}{l}\text { Number of } \\
\text { Segments }\end{array}$ & $\begin{array}{c}\text { Number of Items per } \\
\text { Segment }\end{array}$ & $\begin{array}{l}\text { Number of } \\
\text { Segments }\end{array}$ & $\begin{array}{c}\text { Number of Items per } \\
\text { Segment }\end{array}$ \\
\hline \multirow{3}{*}{ Total } & $N$ & 163 & 163 & 154 & 154 \\
\hline & Mean & 3.20 & 8.83 & 3.82 & 4.30 \\
\hline & Max. & 8 & 73 & 11 & 44 \\
\hline \multirow{3}{*}{$\begin{array}{l}\text { Germany } \\
(\mathrm{N}=56)\end{array}$} & $N$ & 52 & 52 & 50 & 50 \\
\hline & Mean & 3.29 & 8.95 & 3.70 & $3.11(-)$ \\
\hline & Max. & 8 & 28 & 11 & 13 \\
\hline \multirow{3}{*}{$\begin{array}{l}\text { France } \\
(\mathrm{N}=50)\end{array}$} & $N$ & 37 & 37 & 32 & 32 \\
\hline & Mean & 3.35 & 10.62 & 3.56 & 6.02 \\
\hline & Max. & 7 & 73 & 7 & 44 \\
\hline \multirow{3}{*}{$\begin{array}{c}\text { UK } \\
(\mathrm{N}=70)\end{array}$} & $N$ & 58 & 58 & 54 & 54 \\
\hline & Mean & 3.05 & $7.24(-)$ & 3.65 & 3.90 \\
\hline & Max. & 7 & 21 & 8 & 22 \\
\hline \multirow{3}{*}{$\begin{array}{c}\text { Italy } \\
(\mathrm{N}=21)\end{array}$} & $N$ & 16 & 16 & 18 & 18 \\
\hline & Mean & 3.06 & 9.52 & $5.11(+)$ & 4.76 \\
\hline & Max. & 5 & 33 & 11 & 14 \\
\hline
\end{tabular}

$(+)$ or (-) : Indicates a significant positive or negative difference in mean in comparison with other countries (t-test, confidence $95 \%$ )

Table 7 presents the number of segments and items per segment by sector for the firms in the sample. We do not observe any significant differences in the findings obtained for each sector. However, we observe that firms in the health care sector report more items per segment and use more segments in the geographic segmentation than firms in other sectors. 
Table 7. Number of segments and items per segment by sector

\begin{tabular}{|c|c|c|c|c|c|}
\hline \multirow[b]{2}{*}{ Industry Sectors } & & \multicolumn{2}{|c|}{ LOB Segmentation } & \multicolumn{2}{|c|}{ GEO. Segmentation } \\
\hline & & $\begin{array}{l}\text { Number of } \\
\text { Segments }\end{array}$ & $\begin{array}{c}\text { Number of Items } \\
\text { per Segment }\end{array}$ & $\begin{array}{l}\text { Number of } \\
\text { Segments }\end{array}$ & $\begin{array}{c}\text { Number of Items } \\
\text { per Segment }\end{array}$ \\
\hline \multirow{3}{*}{ Total } & $N$ & 163 & 163 & 154 & 154 \\
\hline & Mean & 3.20 & 8.83 & 3.82 & 4.30 \\
\hline & $\operatorname{Max}$ & 8 & 73 & 11 & 44 \\
\hline \multirow{3}{*}{$\begin{array}{l}\text { Consumer G\&S } \\
\qquad(\mathrm{N}=39)\end{array}$} & $N$ & 34 & 34 & 24 & 24 \\
\hline & Mean & 3.09 & 7.33 & 3.92 & 3.64 \\
\hline & Max. & 8 & 21 & 11 & 38 \\
\hline \multirow{3}{*}{$\begin{array}{l}\text { Energy \& Materials } \\
\qquad(\mathrm{N}=23)\end{array}$} & $N$ & 19 & 19 & 21 & 21 \\
\hline & Mean & 3.42 & 10.52 & 4.05 & 4.30 \\
\hline & Max. & 7 & 28 & 8 & 22 \\
\hline \multirow{3}{*}{$\begin{array}{l}\text { Health Care Care } \\
\qquad(\mathrm{N}=14)\end{array}$} & $N$ & 9 & 9 & 13 & 13 \\
\hline & Mean & 3.00 & 5.36 & 4.46 & 5.36 \\
\hline & Max. & 5 & 16 & 11 & 23 \\
\hline \multirow{3}{*}{$\begin{array}{l}\text { Industrials } \\
(\mathrm{N}=53)\end{array}$} & $N$ & 45 & 45 & 41 & 41 \\
\hline & Mean & 3.31 & 8.91 & 3.59 & 4.45 \\
\hline & Max. & 6 & 51 & 6 & 19 \\
\hline \multirow{3}{*}{$\begin{array}{c}\text { Information Tech. \& } \\
\text { Telecom } \\
(\mathrm{N}=68)\end{array}$} & $N$ & 56 & 56 & 55 & 55 \\
\hline & Mean & 3.13 & 9.76 & 3.71 & 4.35 \\
\hline & Max. & 7 & 73 & 8 & 44 \\
\hline
\end{tabular}

5.3 Compliance with IFRS 8

We measured compliance with the standard by observing whether the information required or suggested by IFRS 8 was provided by each company in the appendices of their annual report. We did not try to calculate a compliance index. Our findings therefore concern the number and percentage of companies that report the information. In this way we have determined a disclosure rate for each item of information.

Like previous studies on IFRS 8, we are able to study the overall compliance with the standard. We decided to take our analysis of compliance even further by detailing certain factors: the type of segmentation chosen, the country of domicile and the economic sector.

\subsubsection{Overall Compliance}

Overall, compliance by the firms in our sample (table 8) is inferior to the findings obtained by Nichols et al. (2012) for a sample of large international companies and is closer to the findings presented by Crawford et al. (2012) on firms in the UK. Virtually all of the companies (195 out of 197) report ordinary revenues from external customers. This result is close to that (100\%) obtained by Nichols et al. ( 2012 ) for a sample of large European multinationals (blue chip companies - BCC), but higher than the 91\% rate found by Crawford et al. ( 2012 ) for a sample of 150 British firms - FTSE 250. Concerning the first level of information required by IFRS, the level of compliance by companies in our sample is relatively mediocre. Nearly a third of the companies (29\%) do not provide any explanation of the segmentation adopted. The profit or loss indicator is disclosed in $84 \%$ of the cases ( $100 \%$ of the cases for BCC and $89 \%$ for FTSE 250 companies). The total assets indicator is disclosed in $73 \%$ of the cases, that of total liabilities in only $58 \%$ of the cases. This tendency to disclose less information about liabilities is also found in our sample made up of smaller firms.

Apart from data on ordinary revenues from external customers, income statement items required by IFRS 8 under certain conditions are seldom disclosed by the companies in our sample. For example, amortisations are only reported in $69 \%$ of the cases, which is relatively low compared with the findings obtained from the BCC and FTSE 250 samples. Additional information relating to balance sheet items is also rarely disclosed: $48 \%$ of the companies report the value of segment investments (CAPEX) and only $4 \%$ report the value of equity method investments. The leeway allowed by the standard as well as the smaller size of companies studied may help to explain these low disclosure percentages. Either these items were not used by the CODM or they were not included in the calculation of the profit or loss indicator or, finally they were not significant or even included in the firm's reporting.

There is little disclosure of entity-wide information or additional geographic data. We also observe infrequent reporting of the value of non-current geographic segment assets. Some companies maintain secondary segmentation indicators from the earlier IAS14 standard, such as reporting total assets (32\%) or the value of segment investments according to a secondary segmentation (16\%). Further, some companies still report exceptional items even though the IFRS does not call for them.

Finally, most of the companies in the sample report the principle reconciliations (revenues and earnings) while reconciliations of assets and liabilities are less frequently reported. 
Table 8. Compliance with IFRS 8

\begin{tabular}{|c|c|c|c|c|}
\hline & $\mathbf{N}$ & $\begin{array}{c}\% \\
(\mathrm{~N}=197)\end{array}$ & $\begin{array}{c}\text { Results from } \\
\text { Nichols et al. } \\
\quad(2012) \\
N=306\end{array}$ & $\begin{array}{c}\text { Results from } \\
\text { Crawford et } \\
\text { al. }(2012) \\
N=150\end{array}$ \\
\hline \multicolumn{5}{|l|}{ Information required under IFRS 8} \\
\hline Explanation of the segmentation & 140 & $71 \%$ & & \\
\hline Measure of profit or loss & 166 & $84 \%$ & $100 \%$ & $89 \%$ \\
\hline Total assets & 144 & $73 \%$ & $93 \%$ & $83 \%$ \\
\hline Total liabilities & 115 & $\mathbf{5 8 \%}$ & $71 \%$ & $60 \%$ \\
\hline \multicolumn{5}{|l|}{$P \& L$ information required under IFRS 8 (if certain conditions met) } \\
\hline Revenues from external customers & 195 & $99 \%$ & $100 \%$ & $91 \%$ \\
\hline Intersegment revenues & 105 & $53 \%$ & $54 \%$ & $41 \%$ \\
\hline Interest revenue & 30 & $15 \%$ & $23 \%$ & $13 \%$ \\
\hline Interest expense & 30 & $15 \%$ & $14 \%$ & $12 \%$ \\
\hline Depreciation and amortisation & 136 & $69 \%$ & $86 \%$ & $80 \%$ \\
\hline Interest in the profit or loss of associates and JV & 18 & $9 \%$ & $30 \%$ & $39 \%$ \\
\hline Income tax expense or income & 26 & $13 \%$ & $20 \%$ & $8 \%$ \\
\hline Material non-cash items other than depreciation and amortisation & 23 & $12 \%$ & $56 \%$ & $49 \%$ \\
\hline \multicolumn{5}{|c|}{ Balance sheet information required under IFRS 8 if certain conditions met } \\
\hline Investment in associates and JV & 8 & $4 \%$ & $30 \%$ & $31 \%$ \\
\hline Additions to non-current assets (CAPEX) & 94 & $48 \%$ & $73 \%$ & $77 \%$ \\
\hline \multicolumn{5}{|l|}{ Entity-Wide disclosures } \\
\hline Revenues from external customers (LOB and/or Geo) & 107 & $54 \%$ & & $\begin{array}{l}80 \% \text { (Prod) } \\
85 \% \text { (Géo.) }\end{array}$ \\
\hline Non-current assets- GEO. Segmentation & 62 & $31 \%$ & & $53 \%$ \\
\hline Information about major customers & 63 & $32 \%$ & & $21 \%$ \\
\hline \multicolumn{5}{|l|}{ Other information (non required under IFRS 8) } \\
\hline Total Assets (second segmentation) & 63 & $32 \%$ & & $17 \%$ \\
\hline Additions to non-current assets (CAPEX) - Geo. Segmentation & 31 & $16 \%$ & & $14 \%$ \\
\hline Information related to IAS 36 & 30 & $15 \%$ & & \\
\hline Financial result & 17 & $9 \%$ & & \\
\hline Exceptional items & 8 & $4 \%$ & $2 \%$ & \\
\hline \multicolumn{5}{|l|}{ Reconciliations required under IFRS 8} \\
\hline Reconciliation of the revenues & 162 & $82 \%$ & & $85 \%$ \\
\hline Reconciliation of the measures of profit or loss & 143 & $73 \%$ & & $72 \%$ \\
\hline Reconciliation of the total assets & 128 & $65 \%$ & & $79 \%$ \\
\hline Reconciliation of the total liabilities & 104 & $\mathbf{5 3 \%}$ & & $59 \%$ \\
\hline
\end{tabular}

5.3.2 Compliance with IFRS 8 by Type of Segmentation Chosen

At the time of its adoption, IAS 14 ensured that a minimum of geographic segment information was reported. The adoption of IFRS 8 has raised concerns that there will be a decline in disclosure of this information. We have therefore tried to compare compliance with IFRS 8 depending on the type of segmentation used to define the company's operating segments. We have distinguished between a segmentation based on products and services, (LOB segmentation), a segmentation based on geographic sectors (geographic segmentation), and a matrix segmentation based on both LOB and geographic segments (table 9).

We observe that there is no significant difference (t-test of means) between the two main types of segmentation chosen (LOB or geographic), except in the area of "secondary segmentation" information. The firms that choose an LOB segmentation tend to disclose less geographic information on ordinary revenue from external customers, total assets and the CAPEX. The firms whose segmentation is based on geographic segments disclose these items more frequently in a secondary segmentation (LOB). 
Table 9. Compliance with IFRS 8 by type of segmentation

\begin{tabular}{|c|c|c|c|c|c|c|}
\hline & $\begin{array}{c}\text { LOB } \\
\text { Segmentation } \\
(\mathrm{N}=137)\end{array}$ & $\begin{array}{c}\text { GEO. } \\
\text { Segmentation } \\
(N=53)\end{array}$ & $\begin{array}{c}\text { Matrix } \\
\text { Segmentation } \\
(N=7)\end{array}$ & $\begin{array}{c}\text { Total } \\
(N=197)\end{array}$ & $\begin{array}{c}\text { Mean } \\
\text { Difference }\end{array}$ & $\begin{array}{l}\text { Sig } \\
(1)\end{array}$ \\
\hline & Mean & Mean & Mean & Mean & LOB vs Gl & $\mathrm{EO}$ \\
\hline \multicolumn{7}{|l|}{ Information required under IFRS 8} \\
\hline Explanation of the segmentation & $75 \%$ & $60 \%$ & $71 \%$ & $71 \%$ & 0.15 & \\
\hline Measure of profit or loss & $85 \%$ & $81 \%$ & $86 \%$ & $84 \%$ & 0.04 & \\
\hline Total assets & $72 \%$ & $75 \%$ & $71 \%$ & $73 \%$ & $(0.03)$ & \\
\hline Total liabilities & $56 \%$ & $62 \%$ & $71 \%$ & $58 \%$ & $(0.06)$ & \\
\hline \multicolumn{7}{|c|}{ P\&L information required under IFRS 8 (if certain conditions met) } \\
\hline Revenues from external customers & $99 \%$ & $100 \%$ & $100 \%$ & $99 \%$ & $(0.01)$ & \\
\hline Intersegment revenues & $53 \%$ & $53 \%$ & $57 \%$ & $53 \%$ & 0.00 & \\
\hline Interest revenue & $15 \%$ & $15 \%$ & $14 \%$ & $15 \%$ & 0.00 & \\
\hline Interest expense & $15 \%$ & $17 \%$ & $0 \%$ & $15 \%$ & $(0.02)$ & \\
\hline Depreciation and amortisation & $70 \%$ & $68 \%$ & $57 \%$ & $69 \%$ & 0.02 & \\
\hline Interest in the profit or loss of associates and JV & $11 \%$ & $4 \%$ & $14 \%$ & $9 \%$ & 0.07 & \\
\hline Income tax expense or income & $13 \%$ & $13 \%$ & $14 \%$ & $13 \%$ & $(0.00)$ & \\
\hline $\begin{array}{l}\text { Material non-cash items other than depreciation } \\
\text { and amortisation }\end{array}$ & $12 \%$ & $13 \%$ & $0 \%$ & $12 \%$ & $(0.02)$ & \\
\hline \multicolumn{7}{|c|}{ Balance sheet information required under IFRS 8 if certain conditions met } \\
\hline Investment in associates and JV & $4 \%$ & $6 \%$ & $0 \%$ & $4 \%$ & $(0.02)$ & \\
\hline Additions to non-current assets (CAPEX) & $53 \%$ & $38 \%$ & $29 \%$ & $48 \%$ & 0.15 & \\
\hline \multicolumn{7}{|l|}{ Entity-Wide disclosures } \\
\hline $\begin{array}{l}\text { Revenues from external customers (LOB and/or } \\
\text { Geo) }\end{array}$ & $47 \%$ & $74 \%$ & $43 \%$ & $54 \%$ & $(\mathbf{0 . 2 6 )}$ & * \\
\hline Non-current assets- GEO. Segmentation & $34 \%$ & $25 \%$ & $29 \%$ & $31 \%$ & 0.10 & \\
\hline Information about major customers & $31 \%$ & $36 \%$ & $29 \%$ & $32 \%$ & $(0.05)$ & \\
\hline \multicolumn{7}{|l|}{ Other information (non required under IFRS 8) } \\
\hline Total Assets (second segmentation) & $21 \%$ & $60 \%$ & $29 \%$ & $32 \%$ & $(\mathbf{0 . 3 9})$ & $*$ \\
\hline $\begin{array}{l}\text { Additions to non-current assets (CAPEX) - Geo. } \\
\text { Segmentation }\end{array}$ & $12 \%$ & $26 \%$ & $0 \%$ & $16 \%$ & $(0.14)$ & * \\
\hline Information related to IAS 36 & $17 \%$ & $13 \%$ & $0 \%$ & $15 \%$ & 0.04 & \\
\hline Financial result & $9 \%$ & $6 \%$ & $29 \%$ & $9 \%$ & 0.03 & \\
\hline Exceptionalitems & $3 \%$ & $6 \%$ & $14 \%$ & $4 \%$ & $(0.03)$ & \\
\hline \multicolumn{7}{|l|}{ Reconciliations required under IFRS 8} \\
\hline Reconciliation of the revenues & $81 \%$ & $87 \%$ & $71 \%$ & $82 \%$ & $(0.06)$ & \\
\hline Reconciliation of the measures of profit or loss & $73 \%$ & $74 \%$ & $57 \%$ & $73 \%$ & $(0.01)$ & \\
\hline Reconciliation of the total assets & $64 \%$ & $68 \%$ & $57 \%$ & $65 \%$ & $(0.04)$ & \\
\hline Reconciliation of the total liabilities & $52 \%$ & $55 \%$ & $57 \%$ & $53 \%$ & $(0.03)$ & \\
\hline
\end{tabular}

T-Test ; 95\% confidence level

\subsubsection{Compliance with IFRS 8 by Country of Domicile}

An examination of compliance with the standard depending on companies' country of domicile sheds new light on the question. To our knowledge, no other study compares compliance with IFRS 8 by country of domicile. Table 10 presents the rate of compliance for each item by companies in each of the four countries studied and indicates whether this rate is significantly higher (+) or lower (-) than the average for all the other countries.

Italian firms are generally situated in the middle of the sample; they only score below firms in other countries on the disclosure of information on their main customers.

UK firms report significantly richer segment information on total assets and liabilities (indicator and reconciliation) as well as better information on the value of segment investments. Overall, their disclosure rate is often higher than the average of other firms in the sample. However, we observe rates that are generally lower than those obtained by Crawford et al. (2012) for the British companies in their sample. This may be due to an effect linked to the size of the companies, which the Crawford et al. (2012) study seems to confirm. Indeed, they observe that the disclosure rate of FTSE 250 companies is lower than that of the larger FTSE 100 companies.

For many of the items, German companies have a higher rate of disclosure than companies in the other countries, except on total assets and liabilities (indicator and reconciliation).

Finally, French companies often have lower than average disclosure rates, especially on the value of segment CAPEX, information on main customers and the value of depreciations. 
Table 10. Compliance with IFRS 8 by country of domicile

\begin{tabular}{|c|c|c|c|c|c|c|c|c|c|}
\hline & \multicolumn{2}{|c|}{$\begin{array}{l}\text { Germany } \\
(\mathrm{N}=56)\end{array}$} & \multicolumn{2}{|c|}{$\begin{array}{l}\text { France } \\
(\mathrm{N}=50)\end{array}$} & \multicolumn{2}{|c|}{$\begin{array}{c}\mathrm{UK} \\
(\mathrm{N}=70)\end{array}$} & \multicolumn{2}{|c|}{$\begin{array}{l}\text { Italy } \\
(\mathrm{N}=21)\end{array}$} & \multirow{2}{*}{$\begin{array}{c}\text { Total } \\
(N=197) \\
\text { Mean }\end{array}$} \\
\hline & Mean & Sig. & Mean & Sig. & Mean & Sig. & Mean & Sig. & \\
\hline \multicolumn{10}{|l|}{ Information required under IFRS 8} \\
\hline Explanation of the segmentation & $88 \%$ & $(+)$ & $50 \%$ & $(-)$ & $70 \%$ & & $81 \%$ & & $71 \%$ \\
\hline Measure of profit or loss & $80 \%$ & & $82 \%$ & & $87 \%$ & & $90 \%$ & & $84 \%$ \\
\hline Total assets & $63 \%$ & $(-)$ & $64 \%$ & & $84 \%$ & $(+)$ & $86 \%$ & & $73 \%$ \\
\hline Total liabilities & $46 \%$ & $(-)$ & $52 \%$ & & $71 \%$ & $(+)$ & $62 \%$ & & $58 \%$ \\
\hline \multicolumn{10}{|c|}{$P \& L$ information required under IFRS 8 (if certain conditions met) } \\
\hline Revenues from external customers & $100 \%$ & & $98 \%$ & & $99 \%$ & & $100 \%$ & & $99 \%$ \\
\hline Intersegment revenues & $73 \%$ & $(+)$ & $34 \%$ & $(-)$ & $50 \%$ & & $57 \%$ & & $53 \%$ \\
\hline Interest revenue & $23 \%$ & & $18 \%$ & & $9 \%$ & $(-)$ & $10 \%$ & & $15 \%$ \\
\hline Interest expense & $25 \%$ & $(+)$ & $16 \%$ & & $9 \%$ & $(-)$ & $10 \%$ & & $15 \%$ \\
\hline Depreciation and amortisation & $75 \%$ & & $54 \%$ & $(-)$ & $77 \%$ & & $62 \%$ & & $69 \%$ \\
\hline Interest in the profit or loss of associates and JV & $11 \%$ & & $16 \%$ & & $1 \%$ & $(-)$ & $14 \%$ & & $9 \%$ \\
\hline Income tax expense or income & $13 \%$ & & $26 \%$ & $(+)$ & $9 \%$ & & $0 \%$ & $(-)$ & $13 \%$ \\
\hline $\begin{array}{l}\text { Material non-cash items other than depreciation } \\
\text { and amortisation }\end{array}$ & $23 \%$ & $(+)$ & $6 \%$ & & $9 \%$ & & $5 \%$ & & $12 \%$ \\
\hline \multicolumn{10}{|c|}{ Balance sheet information required under IFRS 8 if certain conditions met } \\
\hline Investment in associates and JV & $2 \%$ & & $6 \%$ & & $0 \%$ & $(-)$ & $19 \%$ & & $4 \%$ \\
\hline Additions to non-current assets (CAPEX) & $46 \%$ & & $24 \%$ & $(-)$ & $64 \%$ & $(+)$ & $52 \%$ & & $48 \%$ \\
\hline \multicolumn{10}{|l|}{ Entity-Wide disclosures } \\
\hline $\begin{array}{l}\text { Revenues from external customers (LOB and/or } \\
\text { Geo) }\end{array}$ & $55 \%$ & & $46 \%$ & & $56 \%$ & & $67 \%$ & & $54 \%$ \\
\hline Non-current assets- GEO. Segmentation & $36 \%$ & & $26 \%$ & & $31 \%$ & & $33 \%$ & & $31 \%$ \\
\hline Information about major customers & $54 \%$ & $(+)$ & $16 \%$ & $(-)$ & $31 \%$ & & $14 \%$ & $(-)$ & $32 \%$ \\
\hline \multicolumn{10}{|l|}{ Other information (non required under IFRS 8) } \\
\hline Total Assets (second segmentation) & $30 \%$ & & $26 \%$ & & $33 \%$ & & $48 \%$ & & $32 \%$ \\
\hline $\begin{array}{l}\text { Additions to non-current assets (CAPEX) - Geo. } \\
\text { Segmentation }\end{array}$ & $18 \%$ & & $8 \%$ & $(-)$ & $16 \%$ & & $29 \%$ & & $16 \%$ \\
\hline Information related to IAS 36 & $20 \%$ & & $16 \%$ & & $13 \%$ & & $10 \%$ & & $15 \%$ \\
\hline Financial result & $9 \%$ & & $12 \%$ & & $6 \%$ & & $10 \%$ & & $9 \%$ \\
\hline Exceptional items & $2 \%$ & & $0 \%$ & $(-)$ & $10 \%$ & $(+)$ & $0 \%$ & $(-)$ & $4 \%$ \\
\hline \multicolumn{10}{|l|}{ Reconciliations required under IFRS 8} \\
\hline Reconciliation of the revenues & $86 \%$ & & $86 \%$ & & $77 \%$ & & $81 \%$ & & $82 \%$ \\
\hline Reconciliation of the measures of profit or loss & $66 \%$ & & $72 \%$ & & $77 \%$ & & $76 \%$ & & $73 \%$ \\
\hline Reconciliation of the total assets & $52 \%$ & $(-)$ & $56 \%$ & & $77 \%$ & $(+)$ & $81 \%$ & & $65 \%$ \\
\hline Reconciliation of the total liabilities & $41 \%$ & $(-)$ & $48 \%$ & & $63 \%$ & $(+)$ & $62 \%$ & & $53 \%$ \\
\hline
\end{tabular}

$(+)$ or (-) : Indicates a significant positive or negative difference in mean in comparison with other countries (t-test, confidence 95\%)

\subsubsection{Compliance with IFRS 8 by Sector}

Table 11 presents the rate of compliance for each item by companies in each of the five sectors studied and indicates whether this rate is significantly higher (+) or lower (-) than the average for all the other sectors. Only the energy and materials sector has a certain number of significant differences on key information. Significant differences are much less numerous for other sectors and only concern a few points.

In general, companies in the energy and materials sector have a slightly higher disclosure rate than the other companies in the sample, especially on key information: explanation of segmentation, profit or loss indicator, segment assets, amortisations, and above all the value of CAPEX. This may be explained by a higher capital intensity companies in the other sectors disclose total assets more than the value of non-current assets in a secondary segmentation. Companies in the consumer goods and services sector mainly underdisclose the amount of segment depreciations. The disclosure rate for non-current asset acquisitions is lower than for firms in the health care sector and is lower than the average, though not significantly, for the same firms for geographic-based reporting. Companies in the industrials sector reveal a lower disclosure rate than that of the other companies in the area of sales data (entity-wide ordinary revenues from external customers and data on main customers). This sector tends to report overall financial results rather than give a detailed breakdown. Finally, companies in the information technology and telecommunications sector essentially stand out for their less frequent reporting of inter-segment revenues. 
Table 11. Compliance with IFRS 8 by sector

\begin{tabular}{|c|c|c|c|c|c|c|}
\hline & $\begin{array}{c}\text { Consumer } \\
\text { G\&S } \\
(\mathrm{N}=39)\end{array}$ & $\begin{array}{l}\text { Energy \& } \\
\text { Materials } \\
(\mathrm{N}=23)\end{array}$ & $\begin{array}{l}\text { Health } \\
\text { Care } \\
(\mathrm{N}=14)\end{array}$ & $\begin{array}{l}\text { Industrials } \\
(\mathrm{N}=53)\end{array}$ & $\begin{array}{l}\text { Information } \\
\text { Tech. \& } \\
\text { Telecom } \\
(\mathrm{N}=68)\end{array}$ & $\begin{array}{c}\text { Total } \\
(N=197)\end{array}$ \\
\hline & Mean (Sig) & $\begin{array}{l}\text { Mean } \\
\text { (Sig) }\end{array}$ & $\begin{array}{l}\text { Mean } \\
(\text { Sig) }\end{array}$ & $\begin{array}{l}\text { Mean } \\
\text { (Sig) }\end{array}$ & Mean (Sig) & Mean \\
\hline \multicolumn{7}{|l|}{ Information required under IFRS 8} \\
\hline Explanation of the segmentation & $74 \%$ & $87 \%(+)$ & $64 \%$ & $62 \%$ & $72 \%$ & $71 \%$ \\
\hline Measure of profit or loss & $74 \%$ & $96 \%(+)$ & $79 \%$ & $89 \%$ & $84 \%$ & $84 \%$ \\
\hline Total assets & $69 \%$ & $91 \%(+)$ & $64 \%$ & $77 \%$ & $68 \%$ & $73 \%$ \\
\hline Total liabilities & $49 \%$ & $57 \%$ & $64 \%$ & $66 \%$ & $57 \%$ & $58 \%$ \\
\hline \multicolumn{7}{|c|}{$P \& L$ information required under IFRS 8 (if certain conditions met) } \\
\hline Revenues from external customers & $97 \%$ & $100 \%$ & $100 \%$ & $98 \%$ & $100 \%$ & $99 \%$ \\
\hline Intersegment revenues & $49 \%$ & $74 \%(+)$ & $57 \%$ & $60 \%$ & $43 \%(-)$ & $53 \%$ \\
\hline Interest revenue & $21 \%$ & $30 \%$ & $21 \%$ & $6 \%(-)$ & $13 \%$ & $15 \%$ \\
\hline Interest expense & $21 \%$ & $26 \%$ & $21 \%$ & $9 \%$ & $12 \%$ & $15 \%$ \\
\hline Depreciation and amortisation & $54 \%(-)$ & $91 \%(+)$ & $57 \%$ & $79 \%$ & $65 \%$ & $69 \%$ \\
\hline $\begin{array}{l}\text { Interest in the profit or loss of associates and } \\
\text { JV }\end{array}$ & $8 \%$ & $22 \%$ & $0 \%(-)$ & $6 \%$ & $10 \%$ & $9 \%$ \\
\hline Income tax expense or income & $15 \%$ & $13 \%$ & $21 \%$ & $11 \%$ & $12 \%$ & $13 \%$ \\
\hline $\begin{array}{l}\text { Material non-cash items other than } \\
\text { depreciation and amortisation }\end{array}$ & $13 \%$ & $13 \%$ & $21 \%$ & $9 \%$ & $10 \%$ & $12 \%$ \\
\hline \multicolumn{7}{|c|}{ Balance sheet information required under IFRS 8 if certain conditions met } \\
\hline Investment in associates and $\mathrm{JV}$ & $3 \%$ & $9 \%$ & $0 \%$ & $4 \%$ & $4 \%$ & $4 \%$ \\
\hline Additions to non-current assets (CAPEX) & $44 \%$ & $70 \%(+)$ & $21 \%(-)$ & $58 \%$ & $40 \%$ & $48 \%$ \\
\hline \multicolumn{7}{|l|}{ Entity-Wide disclosures } \\
\hline $\begin{array}{l}\text { Revenues from external customers (LOB } \\
\text { and/or Geo) }\end{array}$ & $54 \%$ & $61 \%$ & $57 \%$ & $42 \%(-)$ & $62 \%$ & $54 \%$ \\
\hline Non-current assets- GEO. Segmentation & $26 \%$ & $48 \%$ & $29 \%$ & $26 \%$ & $34 \%$ & $31 \%$ \\
\hline Information about major customers & $23 \%$ & $43 \%$ & $43 \%$ & $21 \%(-)$ & $40 \%$ & $32 \%$ \\
\hline \multicolumn{7}{|l|}{ Other information (non required under IFRS 8) } \\
\hline Total Assets (second segmentation) & $36 \%$ & $22 \%$ & $43 \%$ & $28 \%$ & $34 \%$ & $32 \%$ \\
\hline $\begin{array}{l}\text { Additions to non-current assets (CAPEX) - } \\
\text { Geo. Segmentation }\end{array}$ & $18 \%$ & $9 \%$ & $7 \%$ & $21 \%$ & $15 \%$ & $16 \%$ \\
\hline Information related to IAS 36 & $5 \%(-)$ & $13 \%$ & $14 \%$ & $15 \%$ & $22 \%$ & $15 \%$ \\
\hline Financial result & $3 \%(-)$ & $4 \%$ & $7 \%$ & $21 \%(+)$ & $4 \%$ & $9 \%$ \\
\hline Exceptionel items & $5 \%$ & $9 \%$ & $0 \%$ & $4 \%$ & $3 \%$ & $4 \%$ \\
\hline \multicolumn{7}{|l|}{ Reconciliations required under IFRS 8} \\
\hline Reconciliation of the revenues & $90 \%$ & $91 \%$ & $71 \%$ & $81 \%$ & $78 \%$ & $82 \%$ \\
\hline Reconciliation of the measures of profit or loss & $77 \%$ & $87 \%(+)$ & $64 \%$ & $72 \%$ & $68 \%$ & $73 \%$ \\
\hline Reconciliation of the total assets & $67 \%$ & $74 \%$ & $57 \%$ & $70 \%$ & $59 \%$ & $65 \%$ \\
\hline Reconciliation of the total liabilities & $49 \%$ & $48 \%$ & $57 \%$ & $58 \%$ & $51 \%$ & $53 \%$ \\
\hline
\end{tabular}

$(+)$ or $(-)$ : Indicates a significant positive or negative difference in mean in comparison with other industry sectors (t-test, confidence $95 \%$ )

\subsection{Voluntary and/or Detailed Segment Information}

Companies may decide to provide more segment information than required by the accounting standard; we call this voluntary segment information. Further, some information required by the standard is not standardised and may call for the company's own indicators to be reported either because of the way they are defined or calculated. In this part of our study we examine voluntary segment information and non-standardised indicators.

\subsubsection{Voluntary Segment Information: Overall Findings}

The companies in our sample tend to provide extra segment details on revenues $(38 \%$ of the companies in the sample) and/or costs (48\%). This finding is quite remarkable, especially in comparison with the findings of Nichols et al. (2012) who show a $28 \%$ disclosure rate for detailed income statement information in the main segmentation and $2 \%$ in the secondary geographic segmentation.

The income indicators used by companies in the sample may be multiple. Firms mainly report EBIT (69\% of cases), a specific indicator such as operating profit or a particular profit metric (36\%), EBITDA (22\%) or net income (18\%). In comparison with the findings obtained by Nichols et al. (2012) for larger firms $(23 \%, 57 \%, 16 \%$ and $17 \%$ respectively), the intermediate-size European companies studied here prefer a relatively "recognised and common" indicator. The proportion of companies using EBIT is close to the finding (58\%) obtained by Berger and Hann ( 2007 ) in a study based on a sample of American companies applying SFAS 131. Net income 
- an IFRS standardised indicator - is only reported in a segment approach by $18 \%$ of companies. Similar to the proportion found by Nichols et al. (2012), this figure may seem low but this indicator is not necessarily easy to produce for segments and is not necessarily useful in decision making. Detailed information on companies' assets and liabilities is seldom provided, except for non-current assets which are sometimes reported in several segmentations. Without providing any additional remarks, the study by Nichols et al. (2012) indicates the disclosure rate for breakdown of liabilities: $14 \%$ for the operating segmentation and barely $3 \%$ for the secondary geographic segmentation. The intermediate-size companies studied in our sample provide a little more detailed information on assets and liabilities.

Information on segment goodwill is provided by $13 \%$ of companies, on research and development by $3 \%$ and on cash-flows by $4 \%$.

Finally, $9 \%$ of the firms report segment information on non-financial indicators.

\subsubsection{Voluntary Segment Information by Type of Segmentation}

Table 12 presents the findings on voluntary information disclosure by type of segmentation, indicating any significant differences between companies that adopt an LOB segmentation and those that adopt a geographic segmentation.

Overall, the general tendencies previously observed are also found here by type of segmentation.

Companies that adopt an LOB segmentation disclose more details on income statement cost items than those with a geographic segmentation. We also note that they provide generally more information on non-current assets. Indeed, these firms report this indicator in the geographic format and also sometimes in the LOB format.

Table 12. Voluntary segment information by type of segmentation

\begin{tabular}{|c|c|c|c|c|c|c|c|c|}
\hline \multirow[t]{2}{*}{ Voluntary segment information items } & \multicolumn{2}{|c|}{ LOB Segmentation } & \multicolumn{2}{|c|}{$\begin{array}{c}\text { GEO. } \\
\text { Segmentation }\end{array}$} & \multicolumn{2}{|c|}{$\begin{array}{c}\text { Matrix } \\
\text { Segmentation }\end{array}$} & \\
\hline & $N$ & $\%$ & $N$ & $\%$ & $N$ & $\%$ & $N$ & $\%$ \\
\hline & 137 & $100 \%$ & 53 & $100 \%$ & 7 & $100 \%$ & 197 & $100 \%$ \\
\hline Detailed sales items & 40 & $29 \%$ & 13 & $25 \%$ & 3 & $43 \%$ & 56 & $28 \%$ \\
\hline Detailed expenses items & 74 & $54 \%(+)$ & 20 & $38 \%$ & 1 & $14 \%$ & 95 & $48 \%$ \\
\hline $\begin{array}{l}\text { Measure of profit or loss } \\
\text { (other than EBIT. EBITDA or Net Income) }\end{array}$ & 49 & $36 \%$ & 19 & $36 \%$ & 2 & $29 \%$ & 70 & $36 \%$ \\
\hline EBITDA & 35 & $26 \%$ & 8 & $15 \%$ & 0 & $0 \%$ & 43 & $22 \%$ \\
\hline EBIT & 97 & $71 \%$ & 34 & $64 \%$ & 5 & $71 \%$ & 136 & $69 \%$ \\
\hline Net Income & 26 & $19 \%$ & 8 & $15 \%$ & 1 & $14 \%$ & 35 & $18 \%$ \\
\hline Non-current assets & 59 & $43 \%(+)$ & 13 & $25 \%$ & 3 & $43 \%$ & 75 & $38 \%$ \\
\hline Current assets & 15 & $11 \%$ & 5 & $9 \%$ & 3 & $43 \%$ & 23 & $12 \%$ \\
\hline Goodwill & 20 & $15 \%$ & 6 & $11 \%$ & 0 & $0 \%$ & 26 & $13 \%$ \\
\hline $\mathrm{R} \& \mathrm{D}$ & 5 & $4 \%$ & 1 & $2 \%$ & 0 & $0 \%$ & 6 & $3 \%$ \\
\hline Non-current liabilities & 9 & $7 \%$ & 5 & $9 \%$ & 1 & $14 \%$ & 15 & $8 \%$ \\
\hline Current liabilities & 9 & $7 \%$ & 5 & $9 \%$ & 1 & $14 \%$ & 15 & $8 \%$ \\
\hline Cash flows & 6 & $4 \%$ & 1 & $2 \%$ & 1 & $14 \%$ & 8 & $4 \%$ \\
\hline Non financial items & 11 & $8 \%$ & 5 & $9 \%$ & 1 & $14 \%$ & 17 & $9 \%$ \\
\hline
\end{tabular}

$(+)$ or (-) : Indicates a significant positive or negative difference in mean (LOB compared with GEO segmentation)(t-test, confidence $95 \%$ )

\subsubsection{Voluntary Segment Information by Country of Domicile}

Voluntary information disclosure rates depending on companies' country of domicile are presented in Table 15, which indicates whether this rate is significantly higher (+) or lower (-) than the average for all the other countries.

German companies stand out from the companies of the other countries for their higher disclosure rate of details on ordinary revenues in the income statement and on EBITDA. On the other hand, they disclose less detailed segment information on assets and liabilities.

French companies report more detailed segment information on assets and liabilities and also on cash flows. Moreover, they disclose net segment income more frequently, but are disinclined to report EBITDA.

On average, UK firms disclose less voluntary information, particularly information about the breakdown of balance sheet items, intangibles and cash flows.

Italian firms generally tend to report EBIT, but none of them provides information on segment cash flows. 
Table 12 . Voluntary segment information by country of domicile

\begin{tabular}{|c|c|c|c|c|c|c|c|c|c|c|c|c|c|c|}
\hline & \multicolumn{3}{|c|}{ Germany } & \multicolumn{3}{|c|}{ France } & \multicolumn{3}{|c|}{ UK } & \multicolumn{3}{|c|}{ Italy } & \multicolumn{2}{|c|}{ Total } \\
\hline & $N$ & $\%$ & Sig & $N$ & $\%$ & Sig & $N$ & $\%$ & Sig & $N$ & $\%$ & Sig & $N$ & $\%$ \\
\hline $\begin{array}{l}\text { Voluntary segment } \\
\text { information }\end{array}$ & 56 & $100 \%$ & (1) & 50 & $100 \%$ & (1) & 70 & $100 \%$ & (1) & 21 & $100 \%$ & (1) & 197 & $100 \%$ \\
\hline Detailed sales items & 25 & $45 \%$ & $(+)$ & 10 & $20 \%$ & & 16 & $23 \%$ & & 5 & $24 \%$ & & 56 & $28 \%$ \\
\hline Detailed expenses items & 29 & $52 \%$ & & 17 & $34 \%$ & $(-)$ & 37 & $53 \%$ & & 12 & $57 \%$ & & 95 & $48 \%$ \\
\hline $\begin{array}{l}\text { Measure of profit or loss } \\
\text { (other than EBIT. EBITDA or } \\
\text { Net Income) }\end{array}$ & 18 & $32 \%$ & & 22 & $44 \%$ & & 26 & $37 \%$ & & 4 & $19 \%$ & & 70 & $36 \%$ \\
\hline EBITDA & 19 & $34 \%$ & $(+)$ & 2 & $4 \%$ & $(-)$ & 13 & $19 \%$ & & 9 & $43 \%$ & & 43 & $22 \%$ \\
\hline EBIT & 37 & $66 \%$ & & 34 & $68 \%$ & & 47 & $67 \%$ & & 18 & $86 \%$ & $(+)$ & 136 & $69 \%$ \\
\hline Net Income & 5 & $9 \%$ & $(-)$ & 17 & $34 \%$ & $(+)$ & 11 & $16 \%$ & & 2 & $10 \%$ & & 35 & $18 \%$ \\
\hline Non-current assets & 22 & $39 \%$ & & 21 & $42 \%$ & & 22 & $31 \%$ & & 10 & $48 \%$ & & 75 & $38 \%$ \\
\hline Current assets & 2 & $4 \%$ & $(-)$ & 14 & $28 \%$ & $(+)$ & 3 & $4 \%$ & $(-)$ & 4 & $19 \%$ & & 23 & $12 \%$ \\
\hline Goodwill & 8 & $14 \%$ & & 8 & $16 \%$ & & 8 & $11 \%$ & & 2 & $10 \%$ & & 26 & $13 \%$ \\
\hline $\mathrm{R} \& \mathrm{D}$ & 3 & $5 \%$ & & 1 & $2 \%$ & & 0 & $0 \%$ & $(-)$ & 2 & $10 \%$ & & 6 & $3 \%$ \\
\hline Non-current liabilities & 1 & $2 \%$ & & 12 & $24 \%$ & $(+)$ & 0 & $0 \%$ & $(-)$ & 2 & $10 \%$ & & 15 & $8 \%$ \\
\hline Current liabilities & 1 & $2 \%$ & $(-)$ & 12 & $24 \%$ & $(+)$ & 0 & $0 \%$ & $(-)$ & 2 & $10 \%$ & & 15 & $8 \%$ \\
\hline Cash flows & 2 & $4 \%$ & & 6 & $12 \%$ & $(+)$ & 0 & $0 \%$ & $(-)$ & 0 & $0 \%$ & $(-)$ & 8 & $4 \%$ \\
\hline Non financial items & 5 & $9 \%$ & & 7 & $14 \%$ & & 3 & $4 \%$ & & 2 & $10 \%$ & & 17 & $9 \%$ \\
\hline
\end{tabular}

$(+)$ or (-) : Indicates a significant positive or negative difference in mean in comparison with other countries (t-test, confidence $95 \%$ )

\subsubsection{Voluntary Segment Information by Sector}

Table 14 presents the disclosure rate of voluntary information for firms in each of the five sectors studied and indicates whether this rate is significantly higher (+) or lower (-) than the average for all the other sectors.

Overall, the information technology and telecommunications sector and the energy and materials sector tend to disclose more voluntary segment information. Specifically, companies in these sectors provide segment information on certain income statement details (essentially on costs).

Health care sector companies are in the middle with good disclosure of details on assets and liabilities. We might have expected greater disclosure from these companies in the area of intangibles, but it is not the case here.

Finally, companies in the consumer goods and services sector and in industrials provide slightly less voluntary information, especially concerning the breakdown of balance sheet items.

Table 14. Voluntary segment information by sector

\begin{tabular}{|c|c|c|c|c|c|c|c|c|c|c|c|c|}
\hline \multirow[b]{2}{*}{ Voluntary segment information } & \multicolumn{2}{|c|}{$\begin{array}{l}\text { Consumer } \\
\text { G\&S }\end{array}$} & \multicolumn{2}{|c|}{$\begin{array}{l}\text { Energy \& } \\
\text { Materials }\end{array}$} & \multicolumn{2}{|c|}{ Health Care } & \multicolumn{2}{|c|}{ Industrials } & \multicolumn{2}{|c|}{$\begin{array}{l}\text { Information } \\
\text { Tech. \& } \\
\text { Telecom }\end{array}$} & \multicolumn{2}{|c|}{ Total } \\
\hline & $\mathrm{N}$ & $\%$ & $\mathrm{~N}$ & $\%$ & $\mathrm{~N}$ & $\%$ & $\mathrm{~N}$ & $\%$ & $\mathrm{~N}$ & $\%$ & $N$ & $\%$ \\
\hline & 39 & $100 \%$ & 23 & $100 \%$ & 14 & $100 \%$ & 53 & $100 \%$ & 68 & $100 \%$ & 197 & $100 \%$ \\
\hline Detailed sales items & 9 & $23 \%$ & 9 & $39 \%$ & 3 & $21 \%$ & 17 & $32 \%$ & 18 & $26 \%$ & 56 & $28 \%$ \\
\hline Detailed expenses items & 20 & $51 \%$ & 14 & $61 \%$ & 8 & $57 \%$ & 17 & $\begin{array}{c}32 \% \\
(-)\end{array}$ & 36 & $53 \%$ & 95 & $48 \%$ \\
\hline $\begin{array}{l}\text { Measure of profit or loss } \\
\text { (other than EBIT. EBITDA or Net } \\
\text { Income) }\end{array}$ & 13 & $33 \%$ & 11 & $48 \%$ & 4 & $29 \%$ & 16 & $30 \%$ & 26 & $38 \%$ & 70 & $36 \%$ \\
\hline EBITDA & 8 & $21 \%$ & 5 & $22 \%$ & 0 & $\begin{array}{c}0 \% \\
(-)\end{array}$ & 10 & $19 \%$ & 20 & $29 \%$ & 43 & $22 \%$ \\
\hline EBIT & 23 & $59 \%$ & 19 & $83 \%$ & 9 & $64 \%$ & 42 & $\begin{array}{c}79 \% \\
(+)\end{array}$ & 43 & $63 \%$ & 136 & $69 \%$ \\
\hline Net Income & 9 & $23 \%$ & 2 & $9 \%$ & 3 & $21 \%$ & 9 & $17 \%$ & 12 & $18 \%$ & 35 & $18 \%$ \\
\hline Non-current assets & 11 & $28 \%$ & 12 & $52 \%$ & 6 & $43 \%$ & 17 & $32 \%$ & 29 & $43 \%$ & 75 & $38 \%$ \\
\hline Current assets & 3 & $8 \%$ & 3 & $13 \%$ & 3 & $21 \%$ & 6 & $11 \%$ & 8 & $12 \%$ & 23 & $12 \%$ \\
\hline Goodwill & 3 & $8 \%$ & 3 & $13 \%$ & 1 & $7 \%$ & 6 & $11 \%$ & 13 & $19 \%$ & 26 & $13 \%$ \\
\hline $\mathrm{R} \& \mathrm{D}$ & 1 & $3 \%$ & 0 & $\begin{array}{c}0 \% \\
(-)\end{array}$ & 1 & $7 \%$ & 0 & $0 \%(-)$ & 4 & $6 \%$ & 6 & $3 \%$ \\
\hline Non-current liabilities & 1 & $3 \%$ & 2 & $9 \%$ & 3 & $21 \%$ & 3 & $6 \%$ & 6 & $9 \%$ & 15 & $8 \%$ \\
\hline Current liabilities & 1 & $3 \%$ & 2 & $9 \%$ & 3 & $21 \%$ & 3 & $6 \%$ & 6 & $9 \%$ & 15 & $8 \%$ \\
\hline Cash flows & 4 & $10 \%$ & 0 & $\begin{array}{c}0 \% \\
(-)\end{array}$ & 1 & $7 \%$ & 1 & $2 \%$ & 2 & $3 \%$ & 8 & $4 \%$ \\
\hline Non financial items & 3 & $8 \%$ & 2 & $9 \%$ & 0 & $\begin{array}{c}0 \% \\
(-)\end{array}$ & 6 & $11 \%$ & 6 & $9 \%$ & 17 & $9 \%$ \\
\hline
\end{tabular}


$(+)$ or $(-)$ : Indicates a significant positive or negative difference in mean in comparison with other industry sectors (t-test, confidence 95\%)

\section{Conclusion}

The objective of this paper is to examine the implementation of the IFRS 8 standard by intermediate-size European listed companies. At a time when the IASB is beginning its post-implementation review of IFRS 8, this study makes an original contribution to the question by examining the disclosure behaviour of intermediate-size European listed companies whereas most previous studies focused on large companies.

Our study is based on the 2010 annual reports of a sample of 197 companies from four European countries: the UK, France, Germany and Italy. While it confirms the fact that a majority (70\%) of companies choose an LOB segmentation - already observed in earlier studies on large companies - our study highlights specificities in the disclosure behaviour of intermediate-size listed companies as well as national particularities which may be useful to the IASB.

The intermediate-size listed companies in our sample report fewer segments on average than large multinationals, but their disclosure behaviour differs slightly depending on the type of segmentation chosen and the country of domicile. The intermediate-size companies that chose an LOB segmentation report on average 3.15 segments and 11 segment items, compared with 3.45 and 9.79 respectively for those that chose a geographic segmentation. German companies report on average more segments and more segment data than the rest of the sample.

The rate of compliance with IFRS 8 , measured by observing whether the information required or suggested is reported in the appendices of annual reports, is lower than that observed by Nichols et al. (2012) for a sample of European multinationals. While virtually all the intermediate-size companies in our sample report ordinary revenues, few of them (29\%) provide an explanation about their segmentation. Segment assets are reported in $73 \%$ of the cases, but this rate drops to $58 \%$ for segment liabilities. We can conclude then that there is inadequate compliance with IFRS 8. Studies on other standards would allow us to determine whether intermediate-size companies have, on average, a lower rate of compliance with IFRS standards than larger companies. Our study also reveals disparities linked to the geographic origin of companies. For example, German companies have a better disclosure rate than the other companies in the sample for almost every segment item. Conversely, French companies have a lower disclosure rate than the other companies for a large number of items. This generally inadequate level of compliance for the sample as a whole - with differences depending on the geographic origin of the companies studied - raises questions about the implementation of IFRS standards in different countries where they are mandatory and also about the applicability of IFRS 8.

Our study opens up several avenues for future research. First, it would be interesting to analyse whether the segment data reported in appendices is consistent with that reported in other sections of a company's annual report and with that communicated during presentations to financial analysts. Second, an analysis of the reports written by financial analysts on the companies in the sample, possibly supported with interviews, would help us to better understand how analysts use the segment information reported.

\section{References}

Berger, P. G., \& Hann, R. N. (2007). Segment Profitability and the Proprietary and Agency Costs of Disclosure. Accounting Review, 82, 869-906. https://doi.org/10.2308/accr.2007.82.4.869

Bujega, M., Czernkowski, R., \& Bowen, M. (2012). Did IFRS 8 increase segment disclosure? European Accounting Association - Annual Conference - 2012.

CFA-Institute. (2007). A Comprehensive Business Reporting Model - Financial Reporting for Investors. CFA Institute - Centre for Financial Market Integrity.

Chatham, M. (2008). Assessing the extent of compliance with international accounting standards. Journal of International Business research, 7 (1), 61-90.

Crawford, L., Extance, H., Helliar, C., \& Power, D. (2012). Operating Segments: the usefulness of IFRS 8. Edimburgh: ICAS.

Day, J. F. S. (1986). The Use of Annual Reports by UK Investment Analysis. Accounting \& Business Research 16(64), 295-307. https://doi.org/10.1080/00014788.1986.9729330

Doupnik, T. S., \& Seese, L. P. (2001). Geographic area disclosures under SFAS 131: materiality and fineness. Journal of International Accounting, Auditing \& Taxation, 10(2), 117.

https://doi.org/10.1016/S1061-9518(01)00040-4 
Emmanuel, C., \& Gray, S. (1977). Segmental Disclosure and the Segment identification Problem. Accounting and Business Research, 7, 37-50. https://doi.org/10.1080/00014788.1977.9729107

Gray, S. J., \& Radebaugh, L. H. (1984). International Segment Disclosures by U.S. and U.K. Multinational Enterprises: A Descriptive Study. Journal of Accounting Research, 22(1), 351-360. https://doi.org/10.2307/2490716

Herrmann, D. (1996). The Predictive Ability of Geographic Segment Information at the Country, Continent, and Consolidated Levels. Journal of International Financial Management \& Accounting, 7(1), 50-73. https://doi.org/10.1111/j.1467-646X.1996.tb00063.x

Herrmann, D., \& Thomas, W. B. (2000). An Analysis of Segment Disclosures under SFAS No. 131 and SFAS No. 14. Accounting Horizons, 14(3), 287-302. https://doi.org/10.2308/acch.2000.14.3.287

Kang, H., \& Gray, S. (2012). Segment Reporting Practices in Australia: Has IFRS 8 made a Difference? European Accounting Association - Annual Conference - 2012.

KPMG. (2010). The Application of IFRS: Segment reporting. KPMG International Standards Group.

Mechelli, A. (2009). Accounting Harmonization and Compliance in Applying IASB Standards: An Emprirical Survey about the First Time Adoption of IAS 7 by Italian Listed Groups. Accounting in Europe, 6(2), 231-270. https://doi.org/10.1080/17449480903172077

Nichols, N. B., Street, D. L., \& Cereola, S. J. (2012). An analysis of the impact of adopting IFRS 8 on the segment disclosures of European blue chip companies. Journal of International Accounting, Auditing \& Taxation, 21, 79-105. https://doi.org/10.1016/j.intaccaudtax.2012.07.001

Pacter, P. (1970). Line of Business Earnings Disclosures in Recent SEC Filings. Journal of Accountancy, 52-63.

Papa, V., \& Ciesielski, J. (2009). IFRS and 2009 financial statements. CFA Magazine Sept. - Oct. 2009, 16-17. https://doi.org/10.2469/cfm.v20.n5.9

Pisano, S., \& Landriana, L. (2012). The determinants of segment disclosure: an empirical analysis of Italian listed companies. Financial Reporting, 1, 113-132.

Previts, G. J., Bricker, R. J., Robinson, T. R., \& Young, S. J. (1994). A Content Analysis of Sell-Side Financial Analyst Company Reports. Accounting Horizons, 8(2), 55-70.

Street, D. L., \& Bryant, S. M. (2000). Disclosure Level and compliance with IASs: A Comparison of Companies With and Without U.S. Listings and Filings. International Journal of Accounting, 35, 305-330. https://doi.org/10.1016/S0020-7063(00)00060-1

Street, D. L., \& Gray, S. J. (2002). Factors influencing the extent of corporate compliance with International Accounting Standards : summary of a research monograph. Journal of International Accounting, Auditing \& Taxation, 11, 51-76. https://doi.org/10.1016/S1061-9518(02)00054-X

Street, D. L., Nichols, N. B., \& Gray, S. J. (2000). Segment Disclosures under SFAS No. 131: Has Business Segment Reporting Improved? Accounting Horizons, 14(3), 259-285. https://doi.org/10.2308/acch.2000.14.3.259

Tyson, T., \& Jacobs, F. (1987). Segment Reporting in the Banking Industry: Does it meet the criteria of the conceptual framework? Accounting Horizons, December 1987, 35-41.

\section{Copyrights}

Copyright for this article is retained by the author(s), with first publication rights granted to the journal.

This is an open-access article distributed under the terms and conditions of the Creative Commons Attribution license (http://creativecommons.org/licenses/by/4.0/). 